\title{
TRISTES PARALELOS. APONTAMENTOS SOBRE A DISCRIMINAÇÃO E DESAPROPRIAÇÃO DE NATIVOS NO PARANÁ E NA PALESTINA NO SÉCULO $\mathrm{XX}$
}

\section{SAD PARALLELS. NOTES ON DISCRIMINATION AND DISPOSSESSION OF INDIGENOUS IN PARANÁ AND PALESTINE IN THE TWENTIETH CENTURY}

Fábio Bacila Sahd ${ }^{1}$

\begin{abstract}
Resumo: baseado em bibliografia especializada sobre a modernidade e os dois temas específicos, o artigo apresenta, após uma discussão teórica sobre o colonialismo e a representação do colonizado, paralelos entre as perspectivas dos estabelecidos sobre os nativos e seus territórios no Paraná e na Palestina em pleno século XX. Valendo-se dos conceitos de terra nullius, da imagem do colono civilizador e do nativo atrasado e da alegoria de fazer o deserto florescer, bem como de suas aplicações em ambos os espaços, é apontada a ausência oficial dos autóctones dos discursos e análises no "Paraná Novo" e no seio do movimento sionista, o que legitimou desapropriações em massa e a negação de direitos. Delineiam-se ao final algumas diferenças entre ambos os casos. São observações gerais sobre dois capítulos da história do colonialismo e orientalismo, que ajudam o público brasileiro a compreender uma realidade tão distante, mas que guarda semelhanças incômodas com a nossa.
\end{abstract}

Palavras-chave: vazio demográfico; Palestina; racismo; colonização do Paraná.

Summary: based on specialized literature on modernity and on the two specific issues, this paper presents, after a theoretical discussion about colonialism and representation of the colonized peoples, parallels between the perspectives of the established on the natives and on their territories in Paraná and Palestine in the twentieth century. Drawing on concepts of terra nullius, the image of the civilizing colonist and the backwards native and on allegory to make the desert bloom, as well as their applications in both spaces, is pointed to the absence of the indigenous on the official discourses and analyzes in Parana and within the Zionist movement, which legitimized mass dispossession and denial of rights. In the end we outlined some differences between both cases. This are general observations about two chapters of the colonialism and orientalism history, which helps the Brazilian public to understand a so different reality, but a reality that has uncomfortable similarities with ours.

Keywords: demographic void, Palestine, racism, colonization of Paraná.

1 Mestre em História pela Universidade Estadual de Maringá, linha: Política e Movimentos Sociais. 


\section{Introdução: possíveis explicações para a barbárie no Paraná e na Palestina}

Para considerar as analogias entre a exclusão ou invisibilidade dos palestinos e dos indígenas no Oeste, Sudoeste e Norte do Paraná, entre o século XIX e XX, são necessários alguns apontamentos teóricos prévios, que situam os casos em uma estrutura política e econômica comum à modernidade e ao mundo globalizado com suas diferentes regiões integradas pelo capital.

A partir da Revolução Francesa, e com mais fôlego no início do século XX, ao passo que avançaram as discussões e a criação de entidades internacionais para assegurar um mínimo denominador comum às relações dos Estados com seus cidadãos (os direitos humanos e internacionais), foram verificadas diferentes utilizações dos aparatos estatais em todo o globo para reprimir ou eliminar setores "inconvenientes" do seio das sociedades. A modernidade afirmou a lógica do Estado jardineiro, que poda as sociedades, retirando as "ervas daninhas", conforme os interesses do grupo hegemônico. Eugène Enriquez se vale da mitologia grega para considerar a ambiguidade dos novos tempos, que afirmam inequivocamente os direitos de um grupo ao mesmo tempo que negam a própria existência de outros. $O$ amor e a morte compartilhariam do trabalho civilizador e as civilizações seriam as "rainhas da paz e da guerra", fundadas sobre diferenças e critérios de classificação (base de sistemas de dominação) e construídas umas sobre as ruínas de outras².

A colonização sionista da Palestina e do "Paraná Novo" pela sociedade nacional brasileira evidencia essa ambivalência da civilização, que edifica direitos de todo um grupo sobre a negação e os escombros de outros. Lá e cá sociedades milenares foram, inicialmente, negadas e posteriormente desapropriadas e quase desarticuladas, dando lugar a novas relações sociais, integradas ao capital. A tentação do lucro somada a tinturas ideológicas (realização de projetos etnonacionais, garantia de fronteiras, expansão econômica) e revestida por um discurso civilizatório estiveram por trás da "invisibilidade" do outro que vivia sobre os territórios cobiçados. Na Palestina, Eros sustentou a ação coletiva sionista, que

2 BAUMAN, Zygmunt. Modernidade e holocausto. Rio de Janeiro: Jorge Zahar Ed., 1998; ENRIQUEZ, Eugène. Matar sem remorso: reflexões sobre os assassinatos coletivos. In: História: Questões \& Debates. Os lugares da violência. V. 18, n. 35. Curitiba: Editora da UFPR, julho/dezembro de 2001. 
culminou na "jubilosa" criação de um novo país, Israel, idealizado desde o final do século XIX para ser o reduto de todos os judeus em um mundo marcadamente hostil e antissemita. Já Tanatos, face tenebrosa do processo civilizador, revelou-se na perpetração de uma limpeza étnica em larga escala (Nakba) e na destruição de toda uma paisagem e sociedade árabe, tal qual existiram por séculos. No Paraná, Eros edificou as grandes cidades na "selva inóspita" e em seus entornos sulcou a terra preparando-a para os imensos cafezais. Já Tanatos negou a presença milenar de indígenas guarani, xokleng, xetá e kaingang e promoveu assassinatos ou sua redução a terras demarcadas, cujas dimensões são irrisórias. Em ambos os territórios sob litígio os nativos resistiram e ainda resistem, e se o deserto floresceu nas mãos dos colonizadores o fez a partir do sangue e dos corpos daqueles que ali tombaram diante das armas de seus conquistadores.

Nessa tentativa inicial de esboçar alguns pontos que nos permitam compreender a negação e posterior desapropriação de palestinos e de grupos indígenas no Paraná, podemos recorrer à ascensão do racismo "científico" no século XIX e XX. Conforme nos indica Michel Foucault, o vinculo entre a teoria biológica evolucionista e o discurso do poder teria sido estabelecido quase que momentaneamente, resultando em uma politização das categorias que fundamentam a primeira - como a hierarquia das espécies e sua luta pela vida, a crença na evolução e a seleção que elimina os menos aptos. Estes princípios foram aceitos e passaram a transcrever em termos biológicos o discurso político e, assim, legitimaram as relações de colonização e exploração, ocultando interesses nacionais, capitalistas, sociais e políticos sob vestes pseudocientíficas. A humanidade foi dividida em raças mais ou menos capacitadas conforme o grau de cultura desenvolvida (leia-se desenvolvimento material), sendo os europeus ou ocidentais considerados o ápice da cadeia. Sintetizando o pensamento foucaultiano sobre esse ponto, o racismo adentrou na esfera política justamente como condição necessária ao exercício do direito homicida, e poderíamos acrescentar como justificativa para ignorar a presença do outro e o desapropriar ${ }^{3}$.

3 FOUCAULT, Michel. Em defesa da sociedade. São Paulo: Martins Fontes, 1999. 
Na Palestina, o discurso racista e orientalista marcou as representações dos primeiros sionistas europeus em relação aos palestinos e aos próprios judeus "orientais" (vale lembrar a formulação de Herzl "Estado judeu como ponta de lança da civilização em meio à barbárie"). No Brasil as primeiras formulações etnocêntricas em relação aos indígenas - como não tendo "nem fé, nem lei, nem rei" ou mesmo não tendo alma, portanto não sendo seres humanos - parecem ter sido reformuladas a partir do século XIX nos moldes do racismo europeu (populações inferiores, incapazes de ocupar de fato os territórios e produzir cultura, que precisavam ser submetidas e tuteladas). Dessa forma, o progresso material como peso de medida na escala das civilizações foi utilizado para justificar a submissão e redução dos nativos no Paraná e na Palestina. Essas "ações civilizatórias" podem ser vinculadas a objetivos políticos evidentes. Quanto aos palestinos, expropria-los e expulsá-los como condição necessária para constituir um Estado de maioria judaica. No Paraná, colonizar uma área de fronteira, com solos férteis para expandir a cafeicultura, fora justificado como parte do processo de integração nacional, do projeto de ocupação dos "vazios demográficos" e da expansão do agronegócio, elementos centrais nos marcos de uma economia periférica do sistema capitalista.

Muito próximo dessa análise foucaultiana, para explicar as analogias entre indígenas brasileiros e palestinos podemos recorrer a certos elementos da tese orientalista elaborada por Edward Said - passível de ser ampliada para englobar o caso indígena haja vista estes serem considerados não ocidentais, pois objetos da etnohistória (claro, não desconsiderando a especificidade dessa visão e os problemas de aplica-la integralmente ao caso brasileiro). No âmbito político, os diferentes discursos sobre o Oriente - ideológicos, científicos, econômicos, políticos, sociológicos e literários -, alinhados ao poderio das potências industriais e imperiais europeias na transição do XIX para o XX, atuariam no sentido de calar os colonizados e legitimar sua submissão, exploração e, até, extermínio. Afinal, sendo o Ocidente o detentor da melhor e mais avançada cultura e estilo de vida, enfim o farol da humanidade, teria o dever de intervir junto aos povos não ocidentais mais atrasados e levar a eles as "benesses da civilização". Grosso modo, o orientalismo atualiza a milenar oposição entre o nós, civilizados, e eles, os bárbaros, revestindo-a 
de novos caracteres. No contexto do imperialismo, tal discurso maniqueísta se estruturou em torno da contraposição complementar entre um nós ocidental (racional, maduro e virtuoso) e um outro oriental (irracional, imaturo e depravado), que deveria ser civilizado em nome das luzes e do progresso e arrancado da barbárie e infantilidade mental na qual vivia. No Brasil, os "selvagens" não assimilados à sociedade nacional, portanto não civilizados, enquadram-se perfeitamente nessa categoria de outro ou tipo ideal "oriental" (embora residam no hemisfério ocidental, não são detentores de uma cultura europeia ou fortemente influenciada por ela).

$\mathrm{Na}$ visão de Said, três ideias foram interdependentes e moldadas para utilização no contexto internacional pelo colonialismo civilizador do nacionalismo judaico: a não existência dos habitantes árabes, a atitude complementar ocidentalsionista diante de um território vazio e o caráter restaurador e modernizador da empresa sionista. As semelhanças com a colonização da América e de outros rincões da Ásia e África seriam evidentes para esse autor, havendo uma "inequívoca coincidência entre as experiências dos árabes palestinos nas mãos do sionismo e as experiências dos povos negros, amarelos e marrons descritos como inferiores e subhumanos pelos imperialistas do século XIX"4. Paralelamente à divisão corrente e naturalizada entre povos civilizados e não civilizados, cabendo aos primeiros o fardo de governar os segundos e conduzi-los ao progresso, somente os ocidentais teriam uma percepção dignificadora da terra e de sua posse. Apenas o homem civilizado poderia produzir arte e cultura e cultivar a terra, pois esta significa algo para ele. Já os "bárbaros" desdenhariam da terra, deixando-a definhar, portanto, não teriam direito verdadeiro sobre ela. Com base nesses preceitos gerais, aplicáveis a todos os povos colonizados (portanto aos nativos palestinos e americanos), conforme Said,

sociedades nativas inteiras que viviam em territórios da América, África e Ásia foram subitamente cerceadas de seu direito de viver nessas terras, vieram os grandes movimentos desapropriadores do moderno colonialismo europeu, e com eles todos os regimes para redimir a terra, reassentar os nativos, civiliza-los, domesticar seus costumes selvagens e torna-los seres úteis sob controle europeu. A terra na Ásia, África e nas Américas estava lá SAID, Edward W. The Question of Palestine. New York: Vintage Books, 1992. p. 68. 
para a exploração europeia, pois a Europa compreendia o valor da terra de uma forma impossível para os nativos [...] Eu simplifico enormemente a transformação na perspectiva por meio da qual milhões de acres de terra fora da Europa metropolitana foram declarados vazios, seus povos e sociedades definidos como obstáculos ao progresso e desenvolvimento e seu espaço simples e assertivamente decretado como aberto para os colonizadores brancos europeus e sua exploração civilizatória [...] O poder de conquistar territórios é apenas em parte uma questão de força física: existem os fortes componentes morais e intelectuais que tornam a conquista em si secundária em relação a uma ideia, que dignifica (e de fato precipita) a pura força com argumentos retirados da ciência, moralidade, éticas e de uma filosofia geral. Tudo na cultura ocidental potencialmente capaz de dignificar a aquisição de novos domínios - como uma nova ciência, por exemplo, adquire novo território intelectual para ela - pode ser posto a serviço dos aventureiros coloniais ${ }^{5}$.

Na Palestina, os sionistas seriam epígonos dos colonizadores britânicos, que já olhavam para o território como essencialmente vazio, pois preenchido por nativos ignóbeis e dispensáveis, que supostamente aceitariam passivamente os planos que os pretensos superiores tinham para suas propriedades.

Quanto às políticas de integração das comunidades indígenas à nação brasileira e no Paraná, conforme Lucio Tadeu Mota, "nas relações entre os estado colonial, imperial e republicano e as populações indígenas, foi construída toda uma proposição de mundo com a intenção de impor o significado da 'situação colonial' ou da 'ocidentalização' do mundo às populações indígenas no Brasil". Na ótica das elites construtoras do Estado brasileiro ou os autóctones aceitavam se "civilizar" ("seriam conquistados pelas ideias") ou "seriam submetidos (exterminados) pela tecnologia militar dos conquistadores nacionais". As políticas indigenistas, na contramão do discurso protetor dos índios, pautaram-se pelos interesses da sociedade nacional dominante, visando integrar os nativos ao Estado nacional e dissolvê-los nas populações brancas regionais. Elas atendiam "aos interesses das elites agrárias nos movimentos de expansão de seus domínios sobre as terras dos índios". Em suma, tal qual na Palestina, aqui no Brasil e no Paraná "o que esteve em jogo, e ainda continua, é a posse dos territórios indígenas", o que gerou a duradoura resistência dos nativos à desapropriação. Escrevendo especificamente sobre a colonização do Paraná, Mota afirma que

5 SAID, op. cit., p. 76-77. Tradução do autor. 
todos esses territórios, pertencentes às comunidades indígenas Kaingang, Xokleng, Xetá e Guarani, foram espaços submetidos à conquista e à ocupação. Mas, na interpretação da historiografia oficial, eles existem a partir da ação exterior dos conquistadores, e a história que daí surge ignora importantes acontecimentos, tais como as invasões, a conquista, a exploração, os conflitos e a presença dos índios como sujeitos de sua história e que lutaram pela manutenção desses espaços e de seu modo de vida. Essa historiografia não revela os significados construídos pelos sujeitos da época; ela aceita a interpretação de que tais territórios eram espaços 'vazios', prontos para serem ocupados, porque essa interpretação lhe satisfaz, está de acordo com o seu olhar presente sobre novas áreas que estão sendo ocupadas, e as interpretações posteriores repetem essas construções ${ }^{6}$.

Essas analogias entre os indígenas na Palestina e no Paraná têm, irrefutavelmente, uma dimensão econômica comum, baseada na expansão do "sistema capitalista mundial" e na incorporação dessas regiões nele. A gênese desse processo remonta à Europa e à América do século XVI, quando começa a se formar um mercado mundial baseado na divisão internacional do trabalho, e se consolida no século XIX, com a expansão global das relações de intercambio econômico e a integração das nações industrializadas e agrárias no sistema capitalista. As populações nativas do Paraná "novo" e da Palestina se veem forçadas a enfrentar a expansão do capital sobre seus territórios e sua busca pelo lucro e transformação do trabalho, dos recursos naturais e da terra em mercadoria. Essa expansão e inserção dos "marginais" no sistema capitalista em condição periférica, na visão de Immanuel Wallerstein, é uma história partilhada e baseada na conquista militar e na exploração econômica, justificada pela pretensa disseminação do progresso da civilização contra a barbárie estéril7 . Levar o progresso é sinônimo de levar o capitalismo a territórios ermos, desertos ou ocupados por seres incapazes de produção material significativa, o que justifica desapropriações territoriais.

\section{A terra nullius ou o "vazio demográfico"}

6 MOTA, Lucio Tadeu (org.). As cidades e os povos indígenas. Mitologias e visões. Maringá: EDUEM, 2000. p. 5-6; 8-9.

7 WALLERSTEIN, Immanuel. O universalismo europeu: a retórica do poder. Tradução Beatriz Medina. São Paulo: Boitempo, 2007. 
Em ambos os casos prevaleceu no discurso oficial a tese do "vazio demográfico" para legitimar as conquistas territoriais e a espoliação dos nativos, cuja existência fora negada até para eliminar qualquer pudor moral. Não é a toa que, o slogan "uma terra sem povo para um povo sem terra" foi utilizado tanto pelos primeiros sionistas quanto pelos colonos do Oeste, Norte e Sudoeste do Paraná. Inclusive, presidentes brasileiros como Getúlio Vargas, Juscelino Kubitschek e Ernesto Geisel justificaram as "Marchas para o Oeste" nesses termos, o que levou à morte e à desapropriação de milhares de indígenas, sobretudo na Amazônia e no Mato Grosso. Cá e acolá, os nativos foram invisibilizados, privados de sua realidade humana e nacional. Desumanizados e demonizados, seu desaparecimento (ou não aparecimento) foi justificado.

$\mathrm{Na}$ Palestina, os traços dessa percepção orientalista e racista dos habitantes autóctones (comum aos governos e sociedades europeias da época) remontam ao mandato britânico e aos primórdios do movimento sionista. Theodor Herzl defendia a "transferência" dos nativos e a constituição de um Estado judeu como "ponta de lança da civilização europeia contra a barbárie"8. Embora não tivesse como ignorar a presença dos árabes na Palestina, "isso não o impediu de olhar sua presença como manejável", "antevendo de forma arrepiante o que viria a acontecer [sua expulsão e desapropriação em massa]"'. Contudo, essas manifestações mais radicais eram criticadas por vozes dissonantes no movimento. Yitzhak Epstein, em 1907, publicou um artigo intitulado "A questão oculta", criticando a forma como os sionistas estavam adquirindo terras na Palestina e desenraizando os autóctones. Entretanto, mesmo se tratando de um admirador das virtudes árabes, Epstein defendia que os árabes por si só eram incapazes de melhorar sua situação e erradicar a pobreza e ignorância, portanto, deveriam deixar os sionistas se estabelecerem em seu meio para seu próprio bem. Revestido de ideais altruístas, o movimento sionista iria prestar assistência na agricultura, saúde e educação, beneficiando os árabes espiritual e materialmente. Essa percepção homogeneizante e degradante dos árabes como incapazes de criar civilização, portanto eminentemente racista, serviu à 
autoatribuição de direitos sionistas sobre a Palestina/Israel, em detrimento dos nativos não judeus.

Nur Masalha se debruça na percepção territorial dos primeiros colonos e lideranças sionistas para denunciar sua perspectiva racista. Conforme o autor, embasados na ideia da supremacia europeia, esses pioneiros partilhavam da noção de "território vazio" ou "terra sem povo" (terra nullius), como fica explicito em seu principal lema na época: "uma terra sem povo, para um povo sem terra". Ou seja, a Palestina era um espaço representado como vazio, não necessariamente de habitantes, mas de civilização. Era uma terra "estéril, desolada e vazia", o que justificava tanto a colonização quanto o desinteresse pelas consequências trazidas por esta para a população nativa, como seu desenraizamento. Os argumentos mais utilizados nesse sentido eram a ligação superficial dos árabes com a terra e sua incapacidade de cultivá-la. Citando Masalha, "conforme um dos mitos fundadores do sionismo, até a chegada dos colonos judeus europeus a terra tinha permanecido erma, desolada e vazia a espera de Israel que a fertilizaria e a povoaria, pois era propriedade legítima dos 'judeus retornados"'. Masalha cita um trecho de uma obra infantil, que narra a aventura de alguns sionistas pioneiros na Palestina. As semelhanças com o caso paranaense ficam evidentes quando o personagem Joseph diz, "queremos criar um kibutz e conquistar esse vazio [...] Essa terra está vazia, seus filhos tiveram que partir (referindo-se, por suposto, aos hebreus) [...] Ninguém cuida e nem protege essa terra"10.

Para o pai fundador de Israel, David Ben-Gurion, o mérito moral do sionismo e os direitos judaicos sobre a Palestina residiam nos vínculos históricos com ela (percebida como a "terra-natal") e no fato de ser um país estéril, sem um povo apto a cultivá-lo exceto os judeus. Portanto, enquanto estes tinham direitos de propriedade sobre a terra, a população árabe apenas tinha o direito de residir ali. Interessante notar como, analogamente às narrativas sobre a colonização paranaense, na Palestina Gurion e outras lideranças sionistas também mencionaram a paradigmática colonização do Oeste dos Estados Unidos para legitimar seu movimento civilizatório, chegando, inclusive, a se referir aos palestinos como "índios 
vermelhos"11. Com argumentos muito semelhantes, um artigo de 1918 escrito por Aaron David Gordon reforçava esse discurso da terra nullius. Ele justificava o direito dos judeus à Palestina à medida que nenhuma força viva e criativa tomou posse dela. Ela que outrora "jorrava leite e mel", foi deixada estéril, deserta e quase vazia de vida. Portanto, esperava o retorno dos "hebreus".

Aos olhos dos colonos, que chegavam (e ainda chegam) para "redimir a terra bíblica", os nativos eram invisíveis, portanto "privados de sua realidade humana e nacional e classificados como uma não entidade marginal". Em linhas gerais, acreditando-se superiores, os recém-chegados eram indiferentes e condescendentes com o destino dos autóctones desumanizados e demonizados, que dessa forma tinham seus direitos negados e justificada sua erradicação do território. Um excerto do final da década de 1910, escrito pelo sionista Israel Zangwil, exemplifica essa perspectiva racista do território inerente à ideologia europeia:

se lorde Shaftesbury foi literalmente inexato ao descrever a Palestina como um pais sem povo, em essência tinha razão, na medida em que não existe um povo árabe, que viva em íntima relação com o país, que use seus recursos e que deixe nele uma marca característica; há, no melhor dos casos, um acampamento árabe ${ }^{12}$.

Refletindo sobre tal passagem, Nur Masalha aponta que

nem Zangwill nem Weizmann [importante liderança sionista e ex-presidente de Israel] faziam essas valorações demográficas em um sentido literal, pois não queriam dizer que não havia na Palestina um povo, mas que não havia nenhum povo digno de consideração dentro do marco das noções de supremacia europeia então imperantes [...] nesse sentido, é particularmente reveladora a observação feita por Weizmann a Arthur Ruppin, chefe do departamento de colonização da Agência Judia. Ao ser perguntado por Ruppin sobre os árabes palestinos e sobre como havia conseguido passar adiante a Declaração Balfour em 1917, Weizmann respondeu: os britânicos nos disseram que havia umas centenas de milhares de negros e que estes não tinham nenhum valor ${ }^{13}$.

No território da Palestina que hoje é o Estado de Israel houve uma ruptura drástica desse direito à terra, em 1948. A partir de 1967, quando foram ocupadas as

11 SAID, Edward W. The end of the Peace process: Oslo and after. New York: Vintage Books, 2001. p. 119.

12 MASALHA, Nur. Expulsión de los palestinos. El concepto de "transferencia" en el pensamiento político sionista, 1882-1948. Buenos Aires: Editorial Canaán, 2008. p. 14. Tradução livre do autor.

13 Ibid. Tradução livre do autor. 
Colinas de Golã, a Cisjordânia e a Faixa de Gaza (esta até 2005) uma situação semelhante foi verificada.

Não seria esse caso de "invisibilidade" oficial há pouco mencionado a situação dos indígenas no Brasil e no Paraná? Nesse estado meridional a privação das terras ocorreu de forma gradual desde o século XVI, ganhando ímpeto com a colonização dos campos de Guarapuava e Palmas, nos séculos XVIII e XIX, e do norte, oeste e sudoeste na primeira metade do século XX. Até hoje são comuns os conflitos de terras envolvendo indígenas e grupos de colonos vinculados ao agronegócio, como a reserva de Mangueirinha, "invadida por pistoleiros a serviço de grupos empresariais interessados nas matas de araucárias da área" nos anos 1980 e a situação em volta de Guairá. Enquanto os xetá como povo foram exterminados, os kaingang e guarani no Paraná estão confinados em reservas nas margens de rios, no interior e no entorno de grandes cidades do estado, vivendo em situação de pobreza. Cultivam roças familiares e coletivas, fabricam e comercializam artesanato, trabalham nas fazendas das redondezas e recebem auxílio dos programas sociais estaduais e federais.

Lúcio Tadeu Mota nota com perspicácia como, nos discursos oficiais, livros didáticos, obras e em trabalhos acadêmicos sobre o pioneirismo no norte do Estado são encontradas afirmações de que essas terras "eram 'devolutas', 'selvagens', 'desabitadas', 'estavam abandonadas', 'virgens', 'selváticas', [eram] 'sertão bravio'”. Para os colonizadores dos anos 1920 aos anos 1950, eram terras "desabitadas, vazias, prontas para serem ocupadas e colonizadas. É o mito do vazio demográfico. Ao lado dessa falácia, a classe dominante apaga um dos sujeitos da história: os povos indígenas". A ocupação da região é representada como pacífica, quando em verdade "a conquista dos territórios kaingang foi feita em meio à reação permanente dos índios às vilas que brotavam em suas terras", desde os tempos da colônia até o início do século XX "em todos os territórios ocupados". Nesse percurso, "desenvolveram técnicas de guerra, de guerrilhas, de emboscadas e ataques capaz de fazer frente a um inimigo muito superior a eles" ${ }^{14}$. Mas, "segundo a versão oficial,

14 MOTA, Lúcio Tadeu. As guerras dos índios kaingang. A história épica dos índios kaingang no Paraná (1769-1924). Maringá: EDUEM, 2009. p. 16. 
os povos indígenas simplesmente não existiam", então, como poderiam ter resistido?

Dentro dos marcos da expansão capitalista no estado do Paraná, que incorporou uma nova área a seu sistema produtivo, sedimentou-se a ideologia da construção de um território vazio, desabitado, improdutivo e pronto para ser ocupado pela economia nacional produtiva. Nessa ótica oficial, sustentada pelas companhias colonizadoras, governantes, geógrafos, historiadores, livros didáticos e pelos próprios "pioneiros", o terceiro planalto paranaense, como um "imenso vazio demográfico" ou natureza externa à sociedade "à espera de ser possuída", teria sido colonizado harmoniosa e pacificamente. Conforme Mota, que traça um paralelo com a conquista do Oeste nos Estados Unidos, os nativos eram indissociáveis da própria natureza a ser conquistada e obstáculos a serem vencidos na "marcha do progresso e da civilização". A natureza, ao ser representada como hostil, acabava por legitimar aqueles que lutavam para possuí-la, ou seja, justificava "a ocupação dos espaços que faziam parte de uma outra forma de relação homem/natureza", sobretudo a partir do século XVII "no bojo do processo de acumulação capitalista" que transformou os recursos do meio ambiente em matérias-primas e meios de produção. "Terras desabitadas" geravam fascínio e a sanha pela ocupação, colonização e consequente transformação, que as arrancaria das amarras da selvageria, inserindo-as nos processos produtivos. "Cria-se o vazio demográfico a ser ocupado pela colonização pioneira. Vazio criado pela expulsão ou eliminação das populações indígenas que, desse modo, são colocadas à margem da história"15.

Uma frase de Chaim Weizmann, primeiro presidente de Israel, pode tranquilamente ser transposta para o caso paranaense (trocando-se apenas as características geográficas dos lugares). "Parece como se Deus tivesse coberto o solo da Palestina com as rochas, pântanos e areia, de forma que sua beleza só pode ser desnudada por aqueles que a amam e que dedicam suas vidas a curar suas feridas". Nas palavras de Said, Weizmann passa a impressão "de todo um território essencialmente não utilizado, não apreciado e incompreendido". "Apesar das pessoas que vivem nela, a Palestina era então para ser tornada útil, apreciada e

$15 \quad$ MOTA, op. cit., p. 25. 
compreendida. Os habitantes nativos, curiosamente, foram vistos como em descompasso com a história e, parecia decorrer, eles não estiveram realmente presentes"16.

Da mesma forma, as passagens da obra de Lúcio Tadeu Mota sobre o Paraná podem ter seus sujeitos trocados, que farão completo sentido se aplicadas à colonização da Palestina - malgrado algumas diferenças consideradas na conclusão. Entre 1930 e 1960, o norte do Paraná foi alvo de visitas, excursões, passeios científicos, etc. Os relatórios produzidos a partir dessas experiências embasaram vários textos acadêmicos sobre a região em décadas posteriores, sobretudo no que cabe à demografia e ao suposto pioneirismo. Esse material contribuiu sobremaneira para criar a ideia da região como um "enorme vazio demográfico, quase despovoada"17. A presença indígena nessas terras majoritariamente pertencentes ao poder público (devolutas, no sentido de desocupadas, desabitadas e vagas) era ignorada. A pesquisadora do Conselho Nacional de Geografia, Lysia Maria C. Bernardes, publicara um texto em 1950, afirmando que no oeste do Paraná predominavam as "terras virgens, muitas das quais devolutas". O Norte e o Oeste do Paraná configuravam um imenso sertão, no sentido de um enorme vazio demográfico. Nessa perspectiva, a colonização teria sido um "vasto assalto às terras devolutas do estado", já que em nenhum mapa a presença indígena é acusada. Nas palavras de Lucio Tadeu Mota, "os termos variam, sertão, terras devolutas, boca de sertão, em outras passagens, mata virgem, mas o sentido geral é o de uma região desabitada", colonizada pela Companhia de Terras Norte do Paraná e modificada radicalmente pela cafeicultura, que garantiu a ocupação pela sociedade nacional ${ }^{18}$. Ainda que se soubesse da presença indígena nessas regiões, ela fora abertamente negada, inclusive em escritos posteriores aos anos 1950.

Só os colonos civilizados e não os "bárbaros" podem fazer o "deserto florescer"

\footnotetext{
16 SAID (1992), op. cit., p. 85.

17 MOTA, op. cit., p. 27.

18 MOTA, op. cit., p. 34.
} 
Diretamente relacionada à ideia de vazio demográfico está o mito daqueles intrépidos colonos, únicos capazes de florescer o deserto, tornando suas terras estéreis ou selvagens em áreas produtivas e inseridas no sistema produtivo mundial. Cabia a eles levar os progresso e a civilização a essas áreas remotas, selvagens e vazias, dado seus habitantes originais não estarem de fato presentes, pois sem vínculos reais com a terra, incapazes de estabelecer relações produtivas com o solo que aguarda pacientemente à chegada de seus valentes e argutos conquistadores. Nesse sentido, tal qual na Palestina descrita pelos sionistas, dentro dos marcos civilizacionais racistas de quem podia ocupar a terra, o Norte e o Oeste do Paraná de fato estavam desabitados.

Expandindo a reflexão de Lúcio Tadeu Mota sobre a nova natureza produzida pelos colonos para o caso palestino, é possível constatar que aqui e lá a natureza conhecida e com a qual os indígenas se relacionavam foi drasticamente alterada, criando-se outra em seu lugar. Tratava-se agora de um "novo espaço geográfico", próprio à atuação do capitalismo ou produção de mercadorias e acúmulo de riquezas, muito diferente do espaço tradicional das comunidades indígenas, celeremente ocupado, destruído e reconstruído em função da "sociedade nacional". No Paraná o processo é intensificado a partir dos anos 1930, quando as principais cidades da região foram fundadas por intermédio das companhias colonizadoras, e na Palestina o ponto de virada foi a Guerra de 1948 ou Nakba, quando mais de meio milhão de nativos foram expulsos e mais de quatrocentas de suas aldeias destruídas. A natureza e o espaço que foram sendo constituídos com a colonização são muito diferentes daqueles ocupados pelas comunidades autóctones.

Mas, não cabia aos nativos promover essas mudanças, pois eram incapazes e deveriam ser assimilados ou excluídos para ceder espaço. As terras aguardavam seus conquistadores civilizados, seus "proprietários reais", condutores do progresso. Na Palestina, esse "florescimento" necessário fica evidente em um escrito de Chaim Weizmann, datado de 1941, quando este se referia a sua primeira visita ao território, feita em 1907. Ao caracterizar o país como "um dos cantos mais negligenciados do miseravelmente marginalizado Império turco" o ex-presidente israelense estaria 
utilizando a palavra "negligência" para se referir aos habitantes palestinos, cuja presença "não seria razão suficiente para caracterizar a Palestina como algo além de um território essencialmente vazio e paciente, esperando um povo que mostrasse um cuidado apropriado com ela". Contra a decrepitude e o descaso dos nativos Weizmann pregava a necessidade da energia, vontade e organização judaica para reivindicar e 'redimir' a terra". Na tentativa de atrair apoio para essa empresa transformadora foi criado todo um discurso legitimador que "não atacava tanto as realidades existentes como ignorava elas, crescia ao longo delas e, finalmente, riscaria elas, como uma floresta de grandes árvores apaga um punhado de ervas daninhas" ${ }^{\prime 19}$.

Se na Palestina essa ação civilizadora ficara a cargo dos judeus sionistas europeus, no Paraná fora tarefa de migrantes e das empresas colonizadoras. O ode aos colonizadores oculta a presença pregressa do outro "selvagem". Nas palavras escritas pela geografa Lysia Maria em 1950, referindo-se à colonização promovida pela Companhia de Terras Norte do Paraná, "nas terras da companhia, onde em 1930 não havia um só habitante, vivem hoje duzentas mil almas". Três anos mais tarde o "milagre" da colonização fora ainda mais ressaltado por ela em outro texto: "em consequência da colonização promovida nos últimos vinte anos, por particulares, como também recentemente, pelo Estado, o norte do Paraná que até então não passava de um vasto sertão desabitado é, atualmente, uma das zonas mais prósperas do estado". Na mesma época, a também geógrafa Neyde Prandini dissertava sobre essa transformação "eis porque essa região, que era em 1929 um sertão desconhecido, teve suas florestas inteiramente devastadas, e em seu lugar sucedem-se, a perder de vista, os cafezais; ela está atualmente em grande parte colonizada". Seguindo esse mesmo tom, uma revista editada para as comemorações dos dez anos de fundação de Maringá descrevia esta como a "filha de um pioneirismo heroico e síntese de um perfeito trabalho de colonização [...] Rapidamente, num milagre de colonização, povoou-se o norte paranaense. Amanheceram cidades, enquanto tratores e modernos maquinários derrubaram matas e construíram estradas". A alegoria de "fazer o deserto florescer" foi, inclusive,

19 SAID, 1992, op. cit., p. 85-86. 
utilizada literalmente no contexto da colonização do norte do Paraná. Arthur Thomas, que geriu a companhia "Paraná Plantation" responsável pela colonização da região, falava da irresistibilidade dos mapas com grandes áreas desabitadas para aqueles homens imaginativos, cujo "sonhos logo descortinam um futuro no qual o deserto se cobre de flores e da terra brotam imensas riquezas" ${ }^{20}$.

Sociólogos e historiadores, escrevendo sobre a colonização do Paraná, reforçaram essa visão mitificada de alguns geógrafos sobre o suposto vazio demográfico. Enquanto Temístocles Linhares, escrevendo em 1953, fala em "espaços de sobra" conquistados "sem excesso nem lutas belicosas" e "marcha para o oeste", Wilson Martins constrói sentenças como "ilimitado deserto" e "vazio absoluto" para justificar um Paraná branco e europeu, "sem escravidão, sem negro, sem português e sem índio", somente com imigrantes, portanto com "definição humana" que "não é brasileira"21. Brasil Pinheiro Machado, em 1951, foi ainda mais longe no tempo, afirmando que a colonização luso-brasileira em direção ao sul e ao oeste não foi "nem defensiva nem ofensiva, mas simples migração de nomadismo aproveitador", "descobrimento dos lugares desabitados e seu povoamento compulsório" - quando da ótica indígena tratou-se de um ataque direto aos seus territórios. Recorrendo a Oliveira Viana, Machado coloca o bugreiro como "ponta de lança do processo civilizatório", aquele que executa a "conquista civilizadora da terra", "vence o obstáculo material, que é o índio nômade, povoador infecundo da floresta fecunda". Essa tese das terras indígenas como desabitadas ("largos espaços vazios", "regiões desocupadas", "vazios demográficos" e "terras devolutas") é sustentada nos anos 1960 também por Cecília Westphalen e Altiva Balhana. Não completamente vazias, pois com "a presença de rarefeitos posseiros caboclos, nos seus confins, que não se organizaram em comunidades" ${ }^{\prime 2}$.

Esse impulso colonizador do oeste, norte e sudoeste do Paraná coincidiu com um período da história brasileira quando o governo do Estado Novo "pretendeu construir um Estado capaz de criar uma nova sociedade e de produzir um sentimento de nacionalidade para o Brasil. Uma dimensão-chave desse projeto era a

20 MOTA, op. cit., p. 29; 34; 63-66.

21 MOTA, op. cit., p. 41-42.

22 MOTA, op. cit., p. 48. 
geopolítica, que tinha no território seu foco principal". Então foram criadas instituições a fim de fornecer dados confiáveis para pautar a ação governamental, ajudando o Estado a formular e implementar políticas destinadas a vencer os "vazios territoriais" e integrar o território nacional, a exemplo dos conselhos nacionais de geografia, estatística e cartografia e do Instituo Brasileiro de Geografia e Estatística (IBGE).

Conforme Lúcia Lippi Oliveira, essa noção de “'vazio' territorial atualizava o conceito de 'sertão', entendido como um espaço abandonado", que preocupava as elites brasileiras. Em 1940, Getúlio Vargas lançou a "Marcha para o Oeste", que "retomava nossas antigas tradições coloniais e valorizava principalmente a figura do bandeirante, considerado o grande herói nacional, já que fora ele o responsável pela efetiva conquista do território nacional". O Brasil, segundo o discurso de Vargas, "estaria reatando a campanha dos construtores da nacionalidade, ou seja, os antigos sertanistas". Eis que o governo criou territórios federais (Amapá, Rio Branco - atual Roraima -, Guaporé - atual Rondônia -, Iguaçu e Ponta Porã) e passou a atuar conjuntamente na colonização do norte do Paraná, dando origem a uma série de cidades (Londrina, Maringá, Cianorte, Umuarama). O intuito principal: definir e nacionalizar as fronteiras do Brasil, integrar as regiões limítrofes ao corpo da Pátria, assegurar a presença do Estado nacional, o abastecimento e o escoamento de mercadorias e explorar os recursos naturais. Em poucas palavras, garantir o progresso nacional ocupando, integrando e explorando as várias regiões inóspitas do interior do país. "Integração não apenas territorial, mas racial, moral, cultural e política"23. Anos mais tarde, Juscelino Kubitschek retomaria as "linhas mestras da 'política territorial' varguista (políticas de povoamento, regulando o deslocamento populacional, de transporte e de comunicação)". O maior símbolo dessa nova "Marcha para o Oeste", que seria recuperada mais uma vez em plena Ditadura CivilMilitar, era a construção de Brasília e os deslocamentos de população necessários

23 TRUBILIANO, Carlos Alexandre Barros; MARTINS JUNIOR, Carlos. A Marcha para o Oeste de Cassiano Ricardo: um itinerário para a nação. Anais do XI Encontro Regional da Associação Nacional de História - ANPUH/PR. "Patrimônio Histórico no século XXI". Jacarezinho, 2008. Disponível em: <http://cj.uenp.edu.br/ch/anpuh/textos/002.pdf>. Acesso em 12 mai. 2013. 
para tal. O "candango" retomou o trabalho dos velhos bandeirantes, e mais uma vez a presença indígena fora ignorada ${ }^{24}$.

No Paraná, o governo de Moisés Lupion (1947-1951) - eleito com o apoio dos grupos madeireiros, do qual ele próprio era o mais expressivo representante - foi paradigmático dessa euforia do progresso, verniz do avanço capitalista-colonialista sobre as terras supostamente vazias do Paraná. Os agentes idealistas do Serviço de Proteção ao Índio (SPI) foram substituídos por funcionários descompromissados com os indígenas e o governador atropelou as decisões da Assembleia Legislativa, recrudescendo a repressão cultural, reduzindo as áreas de reserva e cerceando direitos. Conforme aponta Paulo Afonso de Souza Castro, na década de 1940 a política indigenista oficial foi submetida "às prerrogativas do regime de arbítrio que propagava uma marcha para o oeste e a ocupação dos 'vazios demográficos' em nome do "progresso". Tal qual na Palestina, esse movimento, oficialmente legitimado por se tratar do avanço sobre zonas despovoadas à espera dos colonizadores, foi muito desfavorável aos nativos, que tinham seus direitos desrespeitados e suas terras invadidas e reduzidas por decretos. Na ideologia oficial, eles deveriam ser paulatinamente integrados à sociedade nacional, tornando-se mão de obra barata e desaparecendo como etnias singulares.

Suas terras foram alvo de negociatas entre o governo federal, o estadual e as colonizadoras, com a anuência do Ministério da Agricultura e de seu órgão subordinado, o SPI - ainda que este tenha apresentado resistência formal. Oficialmente, a redução das áreas designadas aos indígenas foi fundamenta no pressuposto de que estas seriam mais bem usufruídas pelos colonos brasileiros e estrangeiros. A expropriação foi executada a revelia das comunidades indígenas e da própria oposição burocrática apresentada pelo SPI e pela Assembleia Legislativa do Paraná. A justificativa do governo de Lupion, expressa em nota publicada pela Procuradoria Geral do Estado, expressa bem a imagem discriminatória do outro e a visão do homem branco como produtor do progresso:

24 OLIVEIRA, Lúcia Lippi. O Brasil de JK: a conquista do oeste. Disponível em: <http://cpdoc.fgv.br/producao/dossies/JK/artigos/Brasilia/ConquistaOeste>. Acesso em 15 mai. 2013. 
os silvícolas são elementos negativos ao desenvolvimento da prosperidade material do Estado. Ceder-Ihes mais terras é contribuir para a devastação maior de nossas matas, subtraindo áreas úteis a lavoura racional, para convertê-las em desertos improdutivos. Parece que o Governo já demonstrou solidariedade humana aos aborígenes, cedendo-lhes espaço razoável para as suas exigências de conservação e crescimento, em atenção aos fatores psicológicos e históricos que informam o problema. Preservada a tradição de respeito às origens da nacionalidade, cumpre agora orientar a política agrária no sentido de proteger o esforço pioneiro e estimular sua energia criadora de riquezas e esperanças no futuro promissor da terra paranaense ${ }^{25}$.

Trocando em miúdos, a partir da colonização empreendida por particulares e pelo Estado, o norte do Paraná passou de um "vasto sertão desabitado" para "uma das zonas mais prósperas do estado". Essas formulações se refletiram nas escolas e em livros didáticos, configurando todo o arcabouço discursivo legitimador da ocupação "pioneira", "pacífica" e que levou o progresso para a região até então inóspita. O "vazio demográfico" foi vinculado ao heroísmo e à "epopeia de homens fortes, desbravadores, modernos bandeirantes", capazes de transformar a selva em zonas produtivas, de extensos cafezais. Esse vazio estava repleto de perigos que precisavam ser vencidos, mas dentre eles não estava o índio, elemento ausente das narrativas. Já na Palestina, enquanto uns como Zeev Jabotinsky afirmavam abertamente a inevitabilidade do confronto com os indígenas para a colonização do território, outros preferiam ignorar abertamente sua presença, enquanto esboçavam em segredo os planos de transferência populacional, concretizados em larga escala no ano de 1948. Dessa forma, apesar da resistência pregressa e presente dos nativos à desapropriação e extinção como comunidade diferenciada da sociedade nacional no Paraná e na Palestina, eles foram empurrados para fora das margens da história oficial paranaense e israelense na estranha condição de "presentes ausentes"26.

De um lado o intrépido pioneiro brasileiro e o sionista branco europeu, ambos colonizadores e portadores do progresso, legítimos possuidores e produtores. Do outro lado, ambiguamente, cá e acolá os nativos como elementos presentes, mas ao

25 CASTRO, Paulo Afonso de Souza. Angelo Cretã e a retomada das terras indígenas no sul do Brasil. Curitiba: UFPR, 2011. Dissertação de mestrado apresentada ao programa de pósgraduação em Antropologia Social. Defendida em 30/08/2011. p. 32.

26 MOTA, op. cit., p. 52. 
mesmo tempo ausentes, "estrangeiros nativos", seres incapazes de cultivar a terra, obstáculos ao desenvolvimento, portanto manejáveis conforme os interesses maiores dos representantes da superior civilização ocidental, ou simplesmente da expansão do capital. Demonizado, tornado a quintessência do mal, o nativo foi considerado incapaz de absorver valores, ética e civilização e foi sujeitado a diversos tipos de violência, desapropriado e, não raro, exposto à morte ${ }^{27}$. Submetidos a um processo histórico de "estrangeirização" e cerceamento de direitos, geraram e ainda geram desconfiança e são vistos como outsiders ("de fora"), elementos errantes, indesejados, sem direito à terra. Sua voz, constantemente sufocada por todos os meios disponíveis, torna-se um incômodo quando demanda reconhecimento de direitos e de sua própria existência e afirma ser parte e não corpo estrangeiro. Nas palavras de Eliane Brum, escrevendo sobre os conflitos entre nativos brasileiros e colonos no Mato Grosso do Sul em junho de 2013, "para estas pessoas, o corpo dos indígenas era território a ser violado, como violada foi a sua terra" 28 .

\section{À guisa de conclusão}

Em ambos os espaços, o modelo fora a "Marcha para o Oeste" realizada nos Estados Unidos. Tratava-se de ocupar, colonizar e transformar áreas "vazias" e inóspitas, levando o progresso e a civilização. A presença de seus habitantes nativos ou fora completamente ignorada nas elucubrações e produções enaltecedoras da colonização ou fora considerada como manejável, pois tratar-se-ia de uma ocupação temporária, sem vínculos reais com a terra, portanto realocável em outros locais para dar espaço à marcha ininterrupta e benigna da civilização levada adiante pelos únicos capazes de se apegarem sentimentalmente à terra.

Contudo, são inegáveis algumas especificidades no interior desse cenário comum da ocupação de "territórios vazios" pelos portadores da civilização - bem

$27 \quad$ FANON, Frantz. Los condenados de la tierra. Cidade do México: Fondo de Cultura Económica, 1963. p. 21-22.

28 BRUM, Eliane. Índios, os estrangeiros nativos. Revista Época, 10 jun. 2013. Edição digital, disponível em: <http://revistaepoca.globo.com//Sociedade/eliane-brum/noticia/2013/06/indios-osestrangeiros-nativos.html>. Acesso em 13 jun. 2013. 
esboçado por Edward Said ao pensar a Questão Palestina e traçar paralelos com a colonização de outras partes da Ásia, África e América. A violência física e simbólica ao outro foi comum e o lema "uma terra sem povo para um povo sem terra" fora cunhado para uso externo, pois nos círculos dirigentes do sionismo, das empresas colonizadoras e da "sociedade nacional brasileira" já se sabia que os territórios estavam ocupados e que algo precisava ser feito para "desobstruí-los". Aceitavamse os riscos e a necessidade de dar combate aos habitantes nativos para "redimir" seus territórios e dar início à ocupação "real e produtiva" do solo.

No Paraná, assim como na conjuntura nacional brasileira, "o que estava evidente em termos de política indigenista era a conquista das terras dos índios", sendo esta a meta das populações brancas e do governo. "A ocupação dos vastos territórios pertencentes aos índios esteve na pauta dos governantes, bem como 'das áreas de fronteira da província". Eram os interesses da sociedade regional que determinavam as áreas a serem ocupadas e transformadas em "campos produtivos", bem como o extermínio ou a integração das comunidades indígenas à "civilização". A conquista dos territórios indígenas se iniciou já no século $\mathrm{XVI}$, em nome das coroas de Portugal e Espanha. Acentuou-se no século XVII, com as reduções jesuíticas e as bandeiras paulistas. Prosseguiu no XVIII com a exploração do ouro e diamantes no leito do rio Tibagi e com a construção de fortificações e expedições militares. No XIX, em nome do Estado nacional, foram ocupados os campos de Guarapuava e Palmas, representados como vazios, mas conquistados com a força das armas. O decreto de número 426, datado de 24/07/1848, tornou-se a viga mestra da política indigenista brasileira até os dias de hoje, fixando os nativos em determinadas áreas (reservas), impondo-Ihes a tutela governamental e instituindo o paternalismo administrativo ${ }^{29}$. No século $X X$, "a guerra de conquista continuou, agora em nome do progresso, sob o manto da 'colonização pacífica e harmoniosa' levada adiante pelas companhias de terras que ocuparam, lotearam e venderam os antigos territórios indígenas com o aval institucional do estado do Paraná".

29 PAIVA, Eunice; JUNQUEIRA, Carmen. O Estado contra o índio. São Paulo: PUC, 1985. Apud MOTA (2000), op. cit., p. 6. 
Hoje em dia, a ocupação das últimas matas nativas das áreas indígenas no Paraná é feita em nome da necessidade de construir barragens para gerar energia ${ }^{30}$. Os povos kaingang, xetá, xokleng e guarani lutam pela demarcação de suas terras, já foram realocados em diminutas áreas de reservas ou ainda migraram e, de forma geral, residem em condições miseras em cidades do país, quando não foram exterminados como povo (xetá). Esporadicamente, os conflitos com os colonos se tornam notícias nos grandes meios de comunicação. Aqui o discurso do "vazio demográfico" se sagrou de tal forma que continua a ser reiterado em alguma medida até os dias de hoje nos materiais didáticos e até em produções acadêmicas. Da última década do século $X X$ aos dias de hoje, os direitos territoriais das populações indígenas e quilombolas, assegurados pela Constituição de 1988, vêm sendo representados como obstáculos e cerceados, em prol da expansão do agronegócio e da produção de energia, via barragens. Trata-se do velho discurso, racista e colonialista, do progresso que demanda a remoção de certos "entraves" ${ }^{31}$.

$\mathrm{Na}$ Palestina, ainda no final do século XIX, destarte na própria gestação do movimento sionista, surgiam as primeiras formulações sobre a necessidade de "transferir" os árabes-palestinos para ocupar suas terras. Elas ganharam aderentes e corpo nas primeiras três décadas do século $X X$ até serem transformadas em planos concretos nos anos 1930 e implementadas na forma de uma limpeza étnica em larga escala, entre 1947 e 1949 (o que os palestinos e demais árabes chamaram de "Nakba", ou catástrofe). Pelo menos nos documentos produzidos pela ONU desde a própria expulsão e desapropriação em massa dos palestinos na Nakba, seu direito de retorno e restituição é reconhecido, ainda que na prática até hoje isso não tenha tido efeito algum, pois Israel nega a concessão desse direito, que "ameaça a natureza judaica do Estado". Dele só gozam os supostos descendentes dos hebreus, expulsos há quase dois mil anos pelos antigos romanos.

Da ascensão da Organização pela Libertação da Palestina no final dos anos 1960 em diante, os palestinos passaram a ter voz própria e reconhecimento internacional para sua causa, o que tem gerado pressão e certo isolamento de Israel $30 \quad$ MOTA (2000), op. cit., p. 7-8.

31 BARRETO FILHO, Henyo Trindade. Carta Capital, 11 jun. 2013. A dança das cadeiras na Funai. Disponível em: <http://www.cartacapital.com.br/politica/a-danca-das-cadeiras-na-funai-e-aluta-em-torno-da-destinacao-das-terras-publicas-no-brasil-5537.html>. Acesso em 13 jun. 2013. 
- ainda que não com a força suficiente para assegurar plenamente seus direitos. Aqueles que conseguiram permanecer nos territórios que hoje fazem parte das fronteiras reconhecidas de Israel perderam a maior parte de suas terras, por meio de uma legislação que os considerou "proprietários ausentes presentes". Hoje, as cidades árabes dentro de Israel estão cercadas por povoamentos judaicos, e têm seu crescimento cerceado pelas autoridades. Há uma clara discriminação no emprego dos recursos públicos, em detrimento dos autóctones cristãos e muçulmanos. Já os palestinos expulsos em 1948 vivem em sua maior parte como refugiados desapropriados em condições de miséria na Faixa de Gaza, na Cisjordânia, nos países vizinhos ou em outras partes do globo. Os Palestinos de Gaza estão completamente sitiados e sob estrito controle do ocupante, ainda que a distância. Já na Cisjordânia, o processo de desapropriação e os choques entre palestinos e colonos judeus prosseguem, em clara desvantagem para os primeiros que perdem mais terras a cada dia $^{32}$.

$\mathrm{Na}$ Palestina, ao contrário do mito midiático do "conflito milenar", a origem dos choques entre judeus e árabes coincide com o princípio da colonização sionista no final do século XIX, acirrando-se as tensões a partir da criação do Estado de Israel e da expulsão e desapropriação de centenas de milhares de nativos. No Paraná, e de forma geral no Brasil, desde o século XVI "as populações indígenas travaram inúmeras escaramuças, batalhas, emboscadas e guerras contra os invasores de seus territórios". Citando Lúcio Tadeu Mota, "podemos dizer que as terras que foram doadas pelo governo em léguas aos fazendeiros tiveram que ser conquistadas dos índios palmo a palmo"33.

Em terras canárias, os indígenas foram desumanizados, escravizados, reduzidos em áreas irrisórias em relação a seu território original. Suas terras foram desapropriadas inicialmente sem muita justificativa, depois nas "guerras justas" e finalmente para fins de integração, segurança e desenvolvimento nacional. As vestes de leis e instituições indigenistas protetoras não conseguiram encobrir a realidade da expansão e desapropriação em massa promovida pela sociedade nacional até os

32 Cf: YIFTACHEL, Oren. Ethnocracy. Land and identity politics in Israel/Palestine. Philadelphia: University of Philadelphia Press, 2006.

33 MOTA (2000), op. cit., p. 9-10. 
dias de hoje, com fins econômicos de ocupação e produção. Na Palestina, a empresa colonial se revestiu de pelo menos duas outras relevantes justificativas: o direito histórico dos judeus de "retornarem" à Terra de Israel, após dois mil anos de exílio, e a ocupação da Terra Santa como meio de acelerar a vinda do Messias fermento messiânico que recobre a expansão de parte das colônias na Cisjordânia e as demandas pela expulsão de todos os "impuros" e pela recolonização da Faixa de Gaza.

Em suma, para cessar de exaurir o leitor com essas realidades nefastas, em ambos os territórios - retornando ao fundo comum esboçado por Edward Said - a colonização se justificou pela mesma percepção racista e colonial do "território vazio" e do outro como ser inferior, que deve ser subjugado e gerido para seu próprio bem, como meio de assegurar o progresso. Desgraçadamente, aqui e lá esta ainda é a trágica realidade das populações nativas, curiosamente, nunca coberta como deveria ser pelos grandes meios de comunicação. Enquanto esses grupos padecem de extrema injustiça, o grosso das sociedades permanece indiferente a essas questões, e uma minoria apoia medidas ainda mais radicais para extirpar a presença incomoda desses "estrangeiros nativos" e se apropriar de seus territórios.

\section{Referências bibliográficas}

BARRETO FILHO, Henyo Trindade. Carta Capital, 11 jun. 2013. A dança das cadeiras na Funai. Disponível em: < http://www.cartacapital.com.br/politica/a-dancadas-cadeiras-na-funai-e-a-luta-em-torno-da-destinacao-das-terras-publicas-no-brasil5537.html>.

BAUMAN, Zygmunt. Modernidade e holocausto. Rio de Janeiro: Jorge Zahar Ed., 1998.

BRUM, Eliane. Índios, os estrangeiros nativos. Revista Época, 10 jun. 2013. Edição digital, disponível em: <http://revistaepoca.globo.com//Sociedade/elianebrum/noticia/2013/06/indios-os-estrangeiros-nativos.html>.

CASTRO, Paulo Afonso de Souza. Angelo Cretã e a retomada das terras indígenas no sul do Brasil. Curitiba: UFPR, 2011. Dissertação de mestrado apresentada ao programa de pós-graduação em Antropologia Social. Defendida em 30/08/2011.

ENRIQUEZ, Eugène. Matar sem remorso: reflexões sobre os assassinatos coletivos. In: História: Questões \& Debates. Os lugares da violência. V. 18, n. 35. Curitiba: Editora da UFPR, julho/dezembro de 2001.

FANON, Frantz. Los condenados de la tierra. Cidade do México: Fondo de Cultura Económica, 1963. 
FOUCAULT, Michel. Em defesa da sociedade. São Paulo: Martins Fontes, 1999.

HERZL, Theodor. O Estado judeu. São Paulo: Organização sionista unificada do Brasil, 1947.

MASALHA, Nur. El problema de los refugiados palestinos sesenta años después de la Nakba. Madrid: Casa Arabe, 2011.

. Expulsión de los palestinos. El concepto de "transferencia" en el pensamiento político sionista, 1882-1948. Buenos Aires: Editorial Canaán, 2008.

MOTA, Lucio Tadeu (org.). As cidades e os povos indígenas. Mitologias e visões. Maringá: EDUEM, 2000.

As guerras dos índios kaingang. A história épica dos índios kaingang no Paraná (1769-1924). Maringá: EDUEM, 2009.

OLIVEIRA, Lúcia Lippi. O Brasil de JK: a conquista do oeste. Disponível em: <http://cpdoc.fgv.br/producao/dossies/JK/artigos/Brasilia/ConquistaOeste>.

SAID, Edward W. The Question of Palestine. New York: Vintage Books, 1992.

. The end of the Peace process: Oslo and after. New York: Vintage Books,

2001.

TRUBILIANO, Carlos Alexandre Barros; MARTINS JUNIOR, Carlos. "A Marcha para o Oeste de Cassiano Ricardo: um itinerário para a nação". Anais do XI Encontro Regional da Associação Nacional de História - ANPUH/PR. "Patrimônio Histórico no século XXI". Jacarezinho, $2008 . \quad$ Disponível em: $<$ http://cj.uenp.edu.br/ch/anpuh/textos/002.pdf>.

WALLERSTEIN, Immanuel. O universalismo europeu: a retórica do poder. Tradução Beatriz Medina. São Paulo: Boitempo, 2007.

YIFTACHEL, Oren. Ethnocracy. Land and identity politics in Israel/Palestine. Philadelphia: University of Philadelphia Press, 2006. 